\section{Luteotrophic Activity of Human Growth Hormone (Raben)}

I HAVE devoloped an assay for the measurement of luteotrophin in hypophysectomized adult mice which depends on the increase in the weight of a damaged horn of the uterus (formation of deciduomata). Mice were hypophysectomized on the first day of dicestrus and $48 \mathrm{~h}$ later the endometrium of the right horn of the uterus was injured. Tho animals were injected daily for 5 days with a preparation of luteotrophin commencing immediately after hypophysectomy and killed on the sixth day. The response was rocorded as positive if the weight of the damaged horn was at least $11 \mathrm{mg}$ greater than the woight of the control horn. The results were expressed as the percentage of animals with a positive response and a probit transformation was used for parallel line assays. Details of this method will be published shortly.

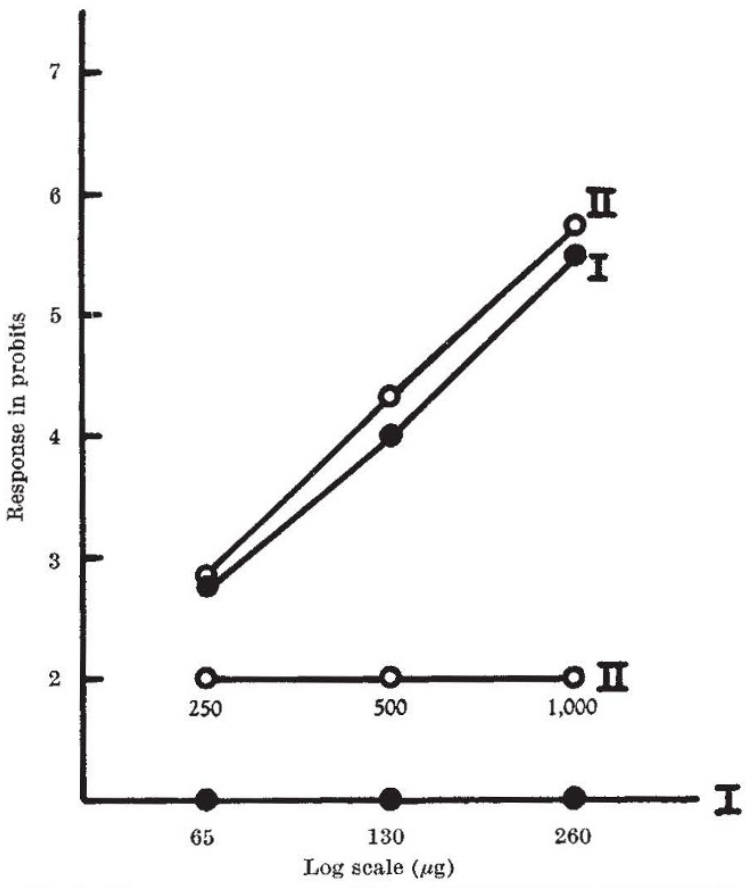

Fig. 1. Dose-response curves of human pituitary growth hormone and of bovine prolactin. I, bovine prolactin, Armour Laboratories, Lot No. $D$ 14083-2B; II, human pituitary growth

$$
\text { hormone (Raben) }
$$

Human growth hormone prepared by the Raben method gave the same effect in hypophysectomized mice as the bovine prolactin, Armour Laboratories, Lot No. $D$ 14083-2B (assumed potency, 20 I.U./mg). In positive responses the difference in weight between the two horns varied from $14.5 \mathrm{mg}$ to $37.4 \mathrm{mg}$ with human growth hormone and from $14.7 \mathrm{mg}$ to $70 \mathrm{mg}$ with bovine prolactin. The doses for human growth hormone were 250,500 and $1,000 \mu \mathrm{g}$ per animal and for the bovine prolactin 65,130 and $260 \mu \mathrm{g}$. The potency of human growth hormone was 29 per cent (95 per cent fiducial limits 17-51) of the refer- ence substance. The results are given in Table 1 and Fig. 1. These figures are in keoping with those previously obtained by the dicstrus method ${ }^{1}$ and are of the same order as the results published by Ferguson and Wallaco ${ }^{2}$.

I am grateful for the supply of human growth hormone, which was prepared by Dr. Anne S. Hartree in the Department of Biochemistry, University of Cambridge, with the aid of a grant from the Medical Research Council to Prof. F. G. Young, and to Armour Laboratories, U.S.A., for the supply of bovine prolactin.

United Birmingham Hospitals.

Nada Kovaćrč

Department of Clinical Endocrinology,

Birmingham and Midland Hospital for Women.

Showell Green Lane,

Birmingham 11.

* Fellow of the World Health Organization.

${ }^{1}$ Kovarið, Nada, Nature, 193, 984 (1962).

'Ferguson, K. A., and Wallace, A. L. C., Nature, 190, 632 (1961).

\section{A Physiological Basis for the 'Optimum' Level of Energy Expenditure}

THE level of oxygen consumption, compared with the maximum intake, at which an individual can work safely for 6-8 $\mathrm{h}$, from month to month, has been variously defined. The Max Planck Arbeitsphysiologie Institute group in Dortmund support the idea that the rate of oxygen intake equivalent to the "Pulsdauerleistungsgrenze" (a heart-rate of about 120 beats/min) is the safe limit. The sole basis of this criterion is that, in their experience, the heart-rate continues to rise and does not remain in a steady state when the level of oxygen consumption has caused the heart-rate to exceed 120 beats $/ \mathrm{min}$. The "Pulsdauerleistungsgrenze" is said to occur at about 30 per cent of the individual's maximum level of oxygen intake ${ }^{1}$. Christensen et al. ${ }^{2}$ have a sounder, even if empirical, basis for their safe limit. They found that men engaged on hard manual work, such as lumberjacking, on high financial incentives, do not, in general, work at a level which exceeds 50 per cent of the maximum level of oxygen intake.

Neither of these criteria has a real physiological basis. An objective and sound physiological basis for the optimum level of work would be the level of oxygen consumption, compared with the maximum oxygen intake, at which the rate of supply of oxygen by cardio-respiratory mechanisms to working muscles no longer balances the rate of expenditure of energy, and anaerobic metabolism commences in working muscles. Increase in blood lactate, alone, is not a reliable index of anaerobic metabolism; Huckabee has demonstrated that 'excess' lactate, derived from the ratio of total-body lactate to pyruvate, is the only reliable measure of anaerobic metabolism ${ }^{3}$. This communication deals with the level of oxygen intake, compared with the maximum, at which 'excess' lactate appears in 6 young Bantu males highly trained on a bicycle ergometer.

These subjects were tested at work-levels from $2,000 \mathrm{ft}$. lb. $/ \mathrm{min}$ to $11,000 \mathrm{ft}$. lb./min on a bicycle

Table 1. Results of an assay of Human Pituitary Growth Hormone using the armour Prolactin lot No. $D$ 14083-2 $B$ (BOVINE) AS A STANDARD

\begin{tabular}{|c|c|c|c|c|c|c|c|c|c|}
\hline \multirow{3}{*}{ Preparation } & \multirow{3}{*}{$\begin{array}{c}\text { Design } \\
\text { of } \\
\text { assay }\end{array}$} & \multirow{2}{*}{$\begin{array}{l}\text { No. of } \\
\text { animals }\end{array}$} & \multirow{3}{*}{$\begin{array}{l}\text { Potency of } \\
\text { unknown } \\
\text { per cent } \\
\text { of standard }\end{array}$} & \multirow{3}{*}{$\begin{array}{c}95 \\
\text { per cent } \\
\text { flducial } \\
\text { limits } \\
\mathbf{1 7 - 5 1}\end{array}$} & \multirow{3}{*}{$\begin{array}{c}\text { Index of } \\
\text { precision } \\
\lambda \\
0.2\end{array}$} & \multirow{3}{*}{$\begin{array}{c}\text { Re- } \\
\text { gression } \\
g \\
0.182\end{array}$} & \multicolumn{3}{|c|}{ Validity tests } \\
\hline & & & & & & & Parallelism & Standard & th hormone \\
\hline & & & & & & & $\begin{array}{cc}t & P \\
0.23 & 0.9-0.8\end{array}$ & $\stackrel{P}{P}$ & 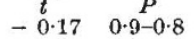 \\
\hline
\end{tabular}

